\title{
Analysis of the Determinants of Food Expenditure Patterns among Urban Households in Nigeria: Evidence from Lagos State.
}

\author{
Babalola $\mathrm{D} \mathrm{A}^{1}$ and Isitor $\mathrm{S} \mathrm{U}^{2}$ \\ ${ }^{I}$ Department of Agricultural Economics and Extension, School of Agric \& Ind. Tech, Babcock University, \\ Ilishan-Remo, Ogun State, Nigeria \\ ${ }^{2}$ Department of Agricultural Economics, Extension and Rural Devpt, College of Agric. Sc, Landmark \\ University, Оти Aran, Kwara State, Nigeria.
}

\begin{abstract}
Emerging body of knowledge suggest the need for food expenditure studies in the urban areas. This study identified the determinants of food expenditure among urban households in Lagos Mainland Local Government Area of Lagos State, Nigeria. Respondents (household heads) were selected randomly and data gathered by means of structured questionnaire. Data analysis was accomplished using descriptive statistics and regression model. Results of the study showed that $60 \%$ of the household income was expended on food which is considered high, suggesting low income and possible high cost of food in the study area. When combined with existing large members (>5) in most households (66\%), existence of food insecurity and vulnerability to poverty in the study area was implied. Regression analysis showed that $65.5 \%$ of the variation in household expenditure on food in the study area was accounted for by the explanatory variables. Household income, tribe, household size and the composition of the household had a significant effect on food expenditure. The authors, therefore, recommended a policy option for general food price subsidy and particularly to address urban food prices which would improve spatial pricing efficiency.
\end{abstract}

Keywords: expenditure, food, income, Lagos, urban

\section{Introduction}

Several studies have focused on analyzing factors associated with consumer choice [1,2]. According to Engel, proportion of expenditure spent on food is inversely related to total income [3,4]. The level of household income is often a major determinant of expenditure patterns of households, and hence differences between patterns of expenditure are largely a reflection of differences in income between household groups or individual households [5]. The proportion of household expenditure on food is usually very significant and can be used in assessing general household consumption. Engel further noted that there is also a higher propensity of households experiencing increasing income to spend a bigger proportion of the food budget on a diversified diet thus improving the nutritional status of the household members. This is especially meaningful in developing countries where food expenditures account for a relatively large share of household income [6]. Household budget surveys across Africa consistently show basic foods to be the main consumption expenditure item in rural and many urban communities $[1,2]$.

Studies have shown that poverty in developing countries, like Nigeria, takes various forms such as low nutritional status, low level of education, decline in the spending on social services, high percentage of household income spent on food, low level of savings, low level of investments and low level of productivity, thus study on household income and expenditure is important in addressing the poverty situation in the country $[7,8,1]$. The nexus between food expenditure, food security, welfare and poverty have been well detailed in previous studies $[9,10,11,12]$. Therefore, with the present pressing need to increase food security and alleviate poverty in Nigeria and most parts of sub-Saharan Africa [13], understanding the determinants of food expenditure is pertinent and of policy relevance.

Most past work on food expenditure has focused more on rural poor household based on the thinking that it is more an issue affecting the rural poor communities but recent studies shows that there is need for more of such study in urban areas $[14,1]$. It is against this backdrop that this study assessed the determinants of food expenditure patterns among urban households.

\subsection{The Concept of Engel's Law}

The Engels law, named after Ernest Engel, was established following the consumption function analysis. The consumption function in its simplest form expresses the quantity of a commodity consumed $\left(\mathrm{q}_{\mathrm{i}}\right)$ as a function of income (y) i. e

$\mathrm{q}_{\mathrm{i}}=\mathrm{f}(\mathrm{y})$......

It also holds that income elasticity is $\leq 1$ for necessities such as food [4]. The following two versions of the Engel's law exist: 
i. The more restrictive version states that as income increases, the proportion of total income spent on food tends to decline, and vice versa. i.e the income elasticity of demand for food is less than unity.

ii. A less restrictive version states that the income elasticities of demand for necessities tend to be low $(\leq 1)$ while those of luxuries tend to be high $(>1)$.

With modification, expenditure on $\mathrm{q}_{\mathrm{i}}$, rather than physical quantity of commodity consumed, is expressed as a function of income especially when the commodity in question is defined as a group of related commodities such as food. Rendering the dependent variable as expenditure is a method of aggregating multi-commodity items [4]. Aside income, other variables are incorporated which influence expenditure such as household size. Furthermore, since income and total expenditure are highly correlated, the consumption function (or better still, expenditure function), following Olayemi [4]., may be expressed as:

$\mathrm{C}_{\mathrm{ij}}=\mathrm{f}\left(\mathrm{E}_{\mathrm{j}} ; \mathrm{N}_{\mathrm{j}}\right)$

Where $C_{i j}$ is expenditure on a group of items $i$ by household $j ; E_{j}$ is the total expenditure by household $j$ and $\mathrm{N}_{\mathrm{j}}$ is the household size. The income elasticity previously referred becomes expenditure elasticity. It is important to note that socio demographic factors such as size of income, level of education, size of family and more have been found to influence household expenditure pattern [15, 3].

\subsection{Effect of Household Income and Family Size on Food Expenditure}

According to Dankwa et al, [16] the total effect of household size on expenditure is a combination of two effects- 'a specific effect' and an 'income effect'. The 'specific effect' results from the increase in need of various commodities when family size increases. The increase in need is usually less than proportional to the increase in size because of the economies of scale in large households. On the other hand, the increase in family size does not increase the need for every commodity in the same proportion and indeed may reduce the need for some. An increase in family size makes people relatively poorer; this is known as the 'income effect'.

One main reason for expenditure analysis is to inform policy regarding the nutritional status of the population for proper targeting as well as streamlining demand and production [1]. The main objective of this study is to analyze the socioeconomic and institutional factors influencing household food expenditure in view of its implication on socio-welfare food security in an urban community in Nigeria. The tested null hypothesis is that the specified explanatory variables do not significantly influence household food expenditure.

\section{Research Methodology}

The study was carried out in Lagos mainland Local Government Area of Lagos State (Nigeria's commercial capital). It is situated in an urban environ where both the rich and poor exists. The area is one of the densely populated areas in Lagos state. It occupies a land area of $19.5 \mathrm{~km}$ square and a total population of 317,720 with 166,163 males and 15,557 females [17].

The study focuses on various food items consumed by selected households. These foods were classified into crop farm produce (such as maize, rice, beans, vegetables e.t.c.), livestock farm products (such as meat, milk e.t.c.), sea foods (fish, shrimps e.t.c.), processed foods (tin foods, garri, fufu e.t.c.), confectionaries (such as sweets, chocolates, biscuits e.t.c.) and the rest were grouped under others. Information was collected with the aid of well structured questionnaires with households being the unit of analysis.

The respondents (household heads) were selected using simple random sampling. Data on household food expenditure was provided by household heads using a memory recall method. A total of one hundred and fifty copies of the questionnaire were administered but 142 were found useful for the analysis. The data gathered were analyzed using descriptive statistics and a multiple regression model.

\section{Model Specification:}

The implicit expenditure function for the regression analysis is given as: $\mathrm{Q}=\mathrm{f}(\mathrm{A}, \mathrm{MS}, \mathrm{FE}, \mathrm{S}, \mathrm{T}, \mathrm{HS}, \mathrm{HI}, \mathrm{HCe})$.

Where:

$\mathrm{Q}=$ Food expenditure (in $\#$ )

$\mathrm{A}=$ Age of household head (in years)

$\mathrm{MS}=$ marital status of household head $($ Married $=1$; Single $=0$ )

$\mathrm{FE}=$ Years of formal education of household head

$\mathrm{S}=\mathrm{Sex}$ of household head $($ Male $=1 ;$ Female $=0)$

$\mathrm{T}=$ Tribe of household head (Yoruba $=0$; otherwise $=1$ )

HS = Household size

$\mathrm{HI}=$ Total monthly household income (synonymous to total expenditure in $\$$ )

$\mathrm{HC}=$ Household composition with respect to dependants \& risk group (pregnant women and infants) $($ low $=0$ high =1)

$\mathrm{e}=$ error term 
Following Olayemi [18], the relationship between the endogenous variable and each of the exogenous variables were examined using linear, exponential, semi-logarithm and double-logarithm functional forms. The lead equation was chosen based on the value of the coefficient of determination $\left(\mathrm{R}^{2}\right)$, statistical significance and economic theory that support expenditure and consumption.

The equations of the functional forms are specified as follow:

$\mathrm{Q}=\mathrm{b}_{0}+\mathrm{b}_{1} \mathrm{~A}+\mathrm{b}_{2} \mathrm{MS}+\mathrm{b}_{3} \mathrm{FE}+\mathrm{b}_{4} \mathrm{~S}+\mathrm{b}_{5} \mathrm{~T}+\mathrm{b}_{6} \mathrm{HS}+\mathrm{b}_{7} \mathrm{HI}+\mathrm{b}_{8} \mathrm{HC}+\mathrm{e}$

Exponential function:

$\mathrm{Ln} \mathrm{Q}=\mathrm{b}_{0}+\mathrm{b}_{1} \mathrm{~A}+\mathrm{b}_{2} \mathrm{MS}+\mathrm{b}_{3} \mathrm{FE}+\mathrm{b}_{4} \mathrm{~S}+\mathrm{b}_{5} \mathrm{~T}+\mathrm{b}_{6} \mathrm{HS}+\mathrm{b}_{7} \mathrm{HI}+\mathrm{b}_{8} \mathrm{HC}+\mathrm{e}$.

Semi $\log$ function:

$\mathrm{Q}=\ln \mathrm{b}_{0}+\mathrm{b}_{1} \ln \mathrm{A}+\mathrm{b}_{2} \ln \mathrm{MS}+\mathrm{b}_{3} \ln \mathrm{FE}+\mathrm{b}_{4} \ln \mathrm{S}+\mathrm{b}_{5} \ln \mathrm{T} \ldots++\mathrm{b}_{8} \ln \mathrm{HC}+\mathrm{e}$

Double log function:

$\mathrm{Ln} \mathrm{Q}=\ln \mathrm{b}_{0}+\mathrm{b}_{1} \ln \mathrm{A}+\mathrm{b}_{2} \ln \mathrm{MS}+\mathrm{b}_{3} \ln \mathrm{FE}+\mathrm{b}_{4} \ln \mathrm{n} \ldots++\mathrm{b}_{8} \ln \mathrm{HC}+\mathrm{e}$

3.1

III. Results And Discussions

Results of Socioeconomic Characteristics of Households

Results in Table 1 shows that 82 percent of the households were male headed and the majority of these household heads were married (76\%) and were between the age of 36 and 45 years $(39 \%)$.

Table 1: Socio-Economic Characteristics of Respondents

\begin{tabular}{|c|c|c|}
\hline Characteristics & Frequency $(n=142)$ & Percentage (\%) \\
\hline \multicolumn{3}{|l|}{ Marital status } \\
\hline Married & 108 & 76.1 \\
\hline Single & 34 & 23.9 \\
\hline \multicolumn{3}{|l|}{ Gender } \\
\hline Male & 116 & 81.7 \\
\hline Female & 26 & 18.3 \\
\hline \multicolumn{3}{|l|}{ Age } \\
\hline$\leq 25$ & 4 & 2.8 \\
\hline $26-35$ & 42 & 29.6 \\
\hline $36-45$ & 56 & 39.4 \\
\hline $46-55$ & 30 & 21.1 \\
\hline$\geq 55$ & 10 & 7.0 \\
\hline \multicolumn{3}{|l|}{ Educational level } \\
\hline Below secondary & 4 & 2.8 \\
\hline Secondary & 22 & 15.5 \\
\hline Above secondary & 116 & 81.7 \\
\hline \multicolumn{3}{|l|}{ Household size } \\
\hline$\leq 4$ & 48 & 33.8 \\
\hline $5-7$ & 56 & 39.4 \\
\hline $8-10$ & 30 & 21.1 \\
\hline$>10$ & 8 & 5.6 \\
\hline \multicolumn{3}{|c|}{ Main occupation of household head } \\
\hline Artisans & 25 & 17.6 \\
\hline Trading & 19 & 13.4 \\
\hline Farming & 38 & 26.8 \\
\hline White collar job/civil service & 60 & 42.3 \\
\hline \multicolumn{3}{|l|}{ Tribe } \\
\hline Yorubas & 100 & 70.4 \\
\hline Non-Yorubas & 42 & 29.6 \\
\hline \multicolumn{3}{|l|}{ *Monthly household Income } \\
\hline$<20,000$ & 34 & 23.9 \\
\hline $20,000-50,000$ & 60 & 42.3 \\
\hline$>50,000$ & 48 & 33.8 \\
\hline \multicolumn{3}{|c|}{ *Monthly Expenditure on food } \\
\hline$<10,000$ & 34 & 23.8 \\
\hline $10,000-20,000$ & 10 & 7.0 \\
\hline $20,000-30,000$ & 50 & 35.2 \\
\hline$>30,000$ & 48 & 33.8 \\
\hline
\end{tabular}

* In naira, $\$ 1 \sim 900625$

Source: Field Survey, 2012.

The age and gender of household head have been reported to impact on food expenditure decision [19]. The majority of the respondents have above secondary formal education (82\%). This educational level is likely due to the fact that the survey was carried out in an urban community. The a priori expectation is that increasing educational status should positively impact on food expenditure [20, 21] however; Ehirim [19] argued that most consumers despite their level of education cannot afford regular food supply. Most of the respondents (70\%) were Yorubas. This is expected since the study was carried out in the south western Nigeria predominated by the Yorubas. Results also showed that the household size of the majority of the surveyed household was between 5 and 7. This is slightly higher than the state average of $\leq 5$ (NBS, 2010). The majority (42\%) of the respondents 
were salaried workers which imply steady flow of income facilitating easy budgeting of expenditure. Most surveyed households $(66 \%)$ earn less than $\$ 50,000$ per month $(<\$ 312.5)$. Household size and income are expected to strongly influence food expenditure $[22,23,24,1]$. Comparing the income with the household size, most members of these households live below $\$ 2$ dollars per day indicating high vulnerability to poverty and food insecurity in the study area. Furthermore, approximately 69 percent of the households spend $>$ N 20,000 $(>\$ 125)$ on food.

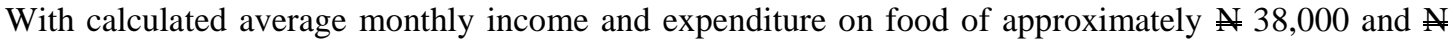
23,000 respectively, over 60 percent of the household income is expended on food consumption in the study area. This is high which could mean the cost of food in urban areas is high. Some of the households even spend more than their income on food which means they will rely on past savings or will result to borrowing. Following Engel's law, this result further calls attention to the welfare and food security status of these households.

\subsection{Regression Result for Determinants of Food Expenditure}

The data on the determinants of household food expenditure was analyzed using double-logarithmic regression equation as lead equation which was chosen based on theoretical and statistical criteria as discussed earlier in the methodology. Food expenditure was the dependent variable while the explanatory variables included age of household head, marital status of household head, level of education, sex, tribe, household size, household income and household composition. The result of the analysis is presented in Table 2.

Table 4.10: Double-log Regression result for household food expenditure

\begin{tabular}{lcc}
\hline Variable & Coefficients & t-value \\
\hline Constant & $7.435^{*}$ & 2.631 \\
Household income & $0.285^{* *}$ & 1.220 \\
Age of household head & -0.789 & -1.020 \\
Marital status & 0.337 & 0.852 \\
Formal education & -0.586 & -0.637 \\
Sex of household head & 0.237 & 0.843 \\
Tribe & $0.874 * *$ & 4.140 \\
Household size & $0.279^{* *}$ & 0.70 \\
Household composition & $0.832^{*}$ & 2.291 \\
\hline
\end{tabular}

**significant at $1 \%$, * significant at $5 \% . \mathrm{R}^{-2}=0.655, \mathrm{~F}-$ ratio $=14.528 *$

Source: Computed from field survey (2012).

The adjusted $\mathrm{R}^{2}$, measures the ability of the explanatory variables to explain all the variation in the dependent variable for the equation is 0.655 which shows that the combine effect of the independent variables accounted for $65.5 \%$ of the variations in the household expenditure on food items. The $\mathrm{F}-$ ratio provides an overall test of significance of the whole function of the regression line. This test shows that $F-$ ratio is statistically significant at 5 percent level of significance.

The result of the regression analysis as presented in Table 2 show that household income, size, composition and tribe significantly and positively influenced expenditure on food at $P \leq 0.05$. This result shows that household will spend more on food with rising household income, household size and presence of dependants and risk group (infants and pregnant women). With relatively low income and high household size in the study area (Table 1) this result calls attention to the need for intervening policy with respect to the nutritional status of the target population especially considering the high cost of food items in the urban communities. Also, non Yorubas will spend more on food. Most non Yoruba indigenes will have preference for their native foods and most of these foods are not cultivated in and around Lagos therefore, cost of purchase is higher due to cost of transportation. The food expenditure elasticity was 0.29 (less than unity) this is expected and consistent with Engel's analysis for necessities such as food.

\section{Conclusion And Recommendation}

The main objective of this study is to find out the determinants of food expenditure among urban households in Lagos state. The effects of variables such as household income, household size, age of household heads, level of education of household head, tribe and sex of household head on food expenditure were investigated. It was observed that household income, tribe, household size and composition of household had a significant effect on food expenditure. there is a suspected existence of food insecurity and vulnerability to poverty in the study area which could be as a result of high cost of food items compared to what is obtained in the rural areas (spatial differential prices), hence people living in urban areas appear not to be better off than those in rural areas in terms of food security because of high cost of food.

Based on the results of this study the following have been recommended: 
i. Better policy attention should be focused on the price control system to food with high nutritional value to be more affordable to urban dwellers. Supportive efforts such as improvement in inter-state transport and road network will ameliorate spatial differential prices.

ii. Provision of subsidies on the food items mostly consumed by infants and pregnant should be explored by government as part of the health and nutrition policy for these groups of citizens.

iii. More studies on food expenditure analysis should focus on urban communities as there are likely evidences of food insecurity and nutritional deficiencies in these communities as obtained in the rural areas.

\section{References}

[1]. Umeh Joseph C. and C. Asogwa Benjamin, Determinants of farm household food expenditure: Implications for food security in rural Nigeria. International Conference on Ecology, Agriculture and Chemical Engineering (ICEACS'2012) December 18-19, 2012 Phuket (Thailand)

[2]. Kyle S C and J. Swinnen, The theory of contested markets and the degree of tradedness of agricultural commodities: An empirical test in Zaria. Journal of African Economy 3, 2010, 93-113.

[3]. Adeniyi O R, Omitoyin S A and O O Ojo, Socio-economic determinants of consumption pattern of fish among households in Ibadan north local government area of Oyo state, Nigeria. African J of food Agriculture, Nutrition and Development. 12(5), 2012

[4]. J. K. Olayemi, Principle of microeconomics for applied economic analysis. SICO Publisher, Ibadan, 2004, ISBN 978-006-432-X

[5]. PROVIDE (Provincial Decision-making Enabling) Project, Household expenditure patterns in South Africa - 1995. Paper in PROVIDE background paper series. Elsenburg September, 2003.

[6]. Dickinson D, Hobbs J, and D. Bailey, A comparison of US and Canadian consumers' willingness to pay for red-meat traceability. The American Agricultural Economics Association Annual Meeting, July 27-30, 2003. Montreal, Canada.

[7]. Njimanted G. F (2006). Econometric model of poverty in Cameroon: A system estimation approach. International Review of Business Research (2): 30-46.

[8]. Tangka F K, R D. Emerson, and M A. Jabbar, Food security effects of intensified dairying - Evidence from Ethiopia highlands. Socio-economic and Policy Research Working Paper 44. 2002, International Livestock Research Institute (ILRI), Nairobi, Kenya.

[9]. Hamelin A M, Habicht J P, and Beaudry M Food insecurity: consequences for the household and broader social implications. Journal of Nutrition 129, 1999, 525-528.

[10]. Hamelin A M, Beaudry M, and J. P Habicht, Characterization of household food insecurity in Quebec: food and feelings. Social Science \& Medicine 54, 2002, 119-132.

[11]. Kirkpatrick S and Tarasuk Valerie, The relationship between low income and household food expenditure patterns in Canada Public Health Nutrition: 6(6), 2003, 589-597

[12]. Obayelu A. E. Okoruwa V. O. and O. A. Oni, Analysis of rural and urban households' food consumption differential in North Central, Nigeria: A Micro-econometric approach. Journal of Development and Agricultural Economics 11(2), $2009,18-20$

[13]. B. T. Omonona, An analysis of food security situation among Nigerian urban households: evidence from Lagos state, Nigeria. Journal of Central European Agriculture 8(3), 2006, 397 - 406.

[14]. T. O. Simbowale, Urban poverty in Nigeria: A Case Study of Agege area of Lagos State, Nigeria., Department of Economics, Faculty of Social Science, University of Ibadan, Ibadan Pg 1-10, Unpublished thesis, 2003

[15]. El-Eraky, M. and T. Al-Muhairi, Consumer demand for food in the United Arab Emirates: A Pilot Study", Proceedings of the Fifth Annual UAE University Research Conference, 2004, Volume 2, Al-Ain.

[16]. Dankwa K.B, Satorius H. J, Zyl V. J and J. F. Kirsten, Expenditure patterns of agricultural household in Lebowa and Venda: effect of farmers support programme on food security'. Agrekon, 31(4), 1992, 222 - 223

[17]. NBS, Nigeria Bureau of Statistics Annual Abstract of Statistics report, 2006, pp: 30-34

[18]. J. K. Olayemi, Elements of applied econometrics. Ibadan University Press, Nigeria. 1998

[19]. N. C. Ehirim, Determinants of consumers' preference for safe chicken consumption in Imo State, Nigeria. Sciencepub journal 2(12), 2010, 42-50.

[20]. Iyangbe C.O. and S.I. Orewa, Determinants of daily protein intake among rural and low-income urban households in Nigeria. American-Eurasian Journal of Scientific Research 4 (4), 2009, 290-301. ISSN 1818-6785 IDOSI Publications.

[21]. J.V. Brawn, The world food situation: An overview". International Food Policy Research Institute. Paper presented for CGIAR Annual General Meeting, Marrakech, Morocco, December 6, 2005

[22]. Mohamed S. Gheblawi and Sherin A. Sherif, Determination of factors affecting expenditures on three major food groups in Al-Ain, the United Arab Emirates (UAE) Emir. J. Food Agric. 19 (2), 2007, 15-23

[23]. C. G. Davis, Socioeconomic determinants of food expenditure Patterns among Racially Different Low-Income Households: An Empirical Analysis. Western Journal of Agricultural Economics, 8(2), 2003, 183 - 196

[24]. E. I. Ibagere Economic analysis on income distribution and household food expenditure pattern in Ibadan metropolis University of Ibadan, 2002, 19 - 25, Unpublished thesis 